\title{
A Feasibility Study on the Transformation from EGP to ESP in College English Teaching in Chinese Non - governmental Colleges and Universities
}

\author{
Wei Wang \\ Changchun Guanghua University
}

Keywords: College English, Teaching Reform, Teaching Mode

\begin{abstract}
College English" as a public basic course, it has been the major teaching content of colleges and universities. However, the state has invested a lot of manpower and material resources, the effect is not satisfactory. In order to change this situation, the majority of front-line teachers and scientific research workers are constantly carrying out college English teaching reform and strive to explore and actively adjust the college English teaching model.
\end{abstract}

\section{The Research Background}

To sum up, since the reform and opening up 30 years, we have experienced three changes in the teaching model:

First, the teacher-based tradition, simple teaching mode. This model is probably from the reform and opening up to 2000 by college English teaching widely used, the teaching mode exists for a long time and the drawbacks are more, such as teaching concept narrow, obsolete, teaching methods monotonous and so on. From the perspective of English as a linguistic subject, it is not conducive to students to master the law of language.

Second, teachers and students interacting, teaching and learning based on the collaborative teaching model. The use of this model is probably from 2001 to 2003, it has to enhance students' oral communication opportunities, improve the initiative of students to learn the advantages and so on. But there are still many problems. Such as teachers still control the right to speak, students learning enthusiasm is still not high.

The third is to teachers as the leading student-centered multimedia teaching model. This model has been extended since 2004, with its modern educational technology features a good mobilization of the enthusiasm of teachers and students. However, English teaching is a process of development, the development of the current teaching model is still inadequate. In this case, the majority of scholars and front-line teachers put forward the timely reform strategies such as: l) how to play the individual characteristics of college English learning; 2) how to effectively carry out extracurricular learning; 3) and to strengthen the application of modern English education technology Mu class, micro class, etc.) and so on. But rarely mention the reform of teaching content.

We have found that the reform of the teaching model has achieved some effect in the specific historical period, but the reform rarely mentions the teaching content and gradually exposes its malpractice over time.

2014 is a crucial year for our English education. First, the Ministry of Education for the implementation of the college entrance examination reform program will be implemented in 2017, then the Ministry of Education proposed from 2014 onwards, a number of local colleges and universities will gradually transition to modern vocational education. That is, on August 18, 2014, Xi Jinping presided over the fourth meeting of the Central Committee for Deepening the Reform of the Reform, which examined the "Opinions on Deepening the Reform of the Examination and Enrollment System Reform", and the proposal the society is widely heated. People in the reflection of the future high school students will accept what kind of English teaching at the same time, it is inevitable to think of the future of the university campus, the students how to learn English? A new 
teaching reform is brewing.

During the summer of 2015, I went to Shijiazhuang to study and listened to Professor Wang Haiqiu of Nanjing University on the development of the "College English Teaching Guide" interpretation, in the teaching objectives, he mentioned that "College English focus on the development of students in the general language skills, Should further enhance its academic English and professional English communication skills and cross-cultural communication skills. "It can be predicted that ESP teaching has become the inevitable trend of college English teaching reform in the new period. Our subject is generated in this context.

Up to now, some domestic colleges and universities have planned or are carrying out the relevant ESP teaching reform and try, which also includes some private institutions. Some institutions have been successful transition. This gives us the transformation of public foreign language teaching has provided unlimited enlightenment.

\section{The Understanding of ESP}

The Difference between ESP and EGP. The definition is different. ESP refers to English for specific purposes, and EGP refers to general English or English for General Purpose.

Course Objectives: Targeting and content selection for specialized English courses is determined by the learner's actual needs for English learning, and the goals and content of the Liberal English curriculum are set by the education authorities or educational institutions to improve the quality of students and cross-cultural communication skills.

The purpose of teaching is different. Comprehensive English is purely language-based or for the purpose of examinations, and ESP teaching is to improve students in English language learning professional language services;

Teaching content is different. Comprehensive English to highlight the general language, text selection tendencies novels and prose, the subject matter is the daily life, and ESP text and student professional background some relationship, but mainly around the professional language characteristics and academic skills; comprehensive English listening to the story And news, practice is the daily life of the conversation, and ESP is listening to the general topic of academic lectures, practicing the campus, classroom and academic discussion of the conversation and so on.

ESP's Four Features and Five Variables. As early as 1988, Strevens proposed four distinguishing features of ESP teaching: "Requirements, curriculum settings must meet the specific needs of learners; content, and specific disciplines and professional-related; language, suitable for these specialties and professional grammar, vocabulary and discourse teaching; and ordinary English contrast.

In 1998, Dudley-Evans amended the ESP definition, removed the fourth point, "contrasting with normal English," and added Strevens's two variable characteristics to five: "ESP may be related to a discipline or Disciplines should be set up; teaching may be used in different ways and learn English; perhaps for adult learners to design, they either in college or work in the company, but may also be middle school students; learning objects are usually senior learners; The learning object must have a basic language foundation, but it can also be a beginner.

\section{The Research Content}

This topic focuses on the following issues:

The Necessity of Transformation. That is to study the problem why to transform. The members of the research group will analyze the current situation of EGP teaching in the context of economic globalization and internationalization of higher education, reveal the shortcomings of traditional EGP teaching, and show the necessity of transition from EGP to ESP.

The Feasibility of Transformation. That is to research whether the transition can be done or not.

Private colleges have the advantages of transformation. Will be mainly from the private colleges and universities of the system, the age of teachers and students to analyze the characteristics of 
three aspects of private colleges and universities to explore the unique advantages of ESP teaching;

ESP's own characteristics. By carefully analyzing the similarities and differences between EGP and ESP and the four characteristics and five variables of ESP, we can conclude that: (1) ESP is learning more extensively. ESP is still language teaching rather than content teaching.

The Ways of Transition. This is to discuss how to transform. And this part is both the focus on this topic but also difficult point. This section focuses on two issues:

Change the teaching model. The research group members will start from the aspects of curriculum, teaching materials, teaching content, teaching evaluation and other aspects to explore the transition from EGP teaching mode to EGP teaching mode, which is the focus of this research;

Change the teaching team. The members of the research group will analyze whether EGP teachers in private colleges are ready for transformation and what challenges will be encountered in the transition process. On this basis, it will explore the effective measures to help EGP teachers to transform ESP teachers. This is the difficult content of this subject;

Protection of Transformation. This section focuses on the following three issues:

Hierarchical teaching is the prerequisite for ESP teaching;

The transformation of teaching model is the key to the development of ESP teaching;

The transformation of the teaching team is the guarantee of ESP teaching success.

\section{Research Methods}

This study is intended to take empirical research methods; to use the questionnaire survey, interviews as a means of research.

First of all, in order to solve the key problem, the research group intends to carry out two questionnaires, tentatively named "college English ESP teaching mode of social survey" and "a private college ESP teaching model student sample survey", the purpose is to obtain the students and The basic data of ESP's knowledge and needs in ESP so as to better grasp the basic positioning of ESP teaching in practical application and explore the effective way of EGP to ESP teaching transformation in private colleges on the basis of analyzing questionnaire data.

Questionnaire design, questionnaire in the design mainly includes the following aspects:

The basic information of the respondents includes: gender, age, occupation, education level, personal understanding of the degree of ESP and understanding, to engage in professional and other basic information.

Surveyed by students and enterprises on ESP awareness of the teaching.

What is the ability of the surveyed student to think that the teacher who teaches ESP will have.

The nature of the business being investigated, what competencies the ESP personnel need to have, and what are the main basis for their consideration of the level of English proficiency.

Open survey: by the survey students and enterprises free to fill in the part, including their ESP teaching recommendations and personal understanding.

The questionnaires were distributed and recovered in the survey.

Online Survey Method for Distribution and Recycling

Telephone interview mode release and recycling questionnaire

Place the door to issue and recycle the questionnaire

E-mail delivery and recycling questionnaires

A random questionnaires were issued and collected in the class

Secondly, in order to overcome the difficult problem, the research group intends to conduct a research on EGP and ESP teachers in a private university, which is divided into two parts: questionnaire and interview. The purpose is to find out the difference between the two, to understand the ESP teachers in the teaching practice of personal experience, so as to promote EGP teachers to better self-positioning, and on this basis to achieve the successful transition of ESP teacher role.

In order to obtain the most accurate and accurate information, the research group through the questionnaire and interviews with a local private sector EGP and ESP teachers made a survey. Through the reading of a large number of references, the author combines the teaching experience 
of EGP and ESP teachers with their own orientation, the enthusiasm of the students in the classroom and the ability of the application to solve the problem of professional English, the degree of communication between the teachers and other subjects. I think this is very necessary. The reason to choose the institution, one is because the author is more familiar with it, easy to investigate the work carried out. In order to facilitate the statistical data and processing, the questionnaire received a closed question and the content is more specific, relatively small classification, a total of 20 topics. And interview to take an open question, in order to give full play to the subjective initiative of the respondents, get a variety of more inclined to the specific answer, the content is more general, a total of seven topics. All questions are taken as a step-by-step heuristic question. There were 30 EGP teachers interviewed, 28 of ESP teachers, and interview content based on the content of Dudley-Evans \& St. John's role theory, with the order AD decreasing in descending order, namely: high - high - general - low a more frequent - general - less. In all the teachers of different professional randomly selected five EGP and ESP teachers for interviews.

\section{The Meaning of the Subject}

Theoretically, to help us find new problems, sum up the new law, to further enrich and improve the private universities in China ESP teaching research deficiencies, in theory for a more in-depth understanding of private colleges and universities EGP and ESP relationship between the how to better change from EGP teaching to ESP teaching, how to carry out more effective private colleges and universities to lay the theoretical foundation of ESP teaching.

In practice, it can provide some inspiration and reference for EGP and ESP teachers and other scientific research personnel in other institutions. It is helpful to realize the unification of EGP teaching and ESP teaching practice, which is helpful to optimize college English teaching resources and improve classroom teaching effect, and this transformation is also the need of real implementation of college English teaching objectives, better response to the international challenges of economic globalization and educational internationalism.

\section{References}

[1] Li Yongjun. Special vocational English teaching in the status quo and countermeasures [J] .2007 (6)

[2] Cai Ji-gang.Study on the Characteristics and Countermeasures of College English Teaching in Transitional Period [J]. Foreign Languages and Studies 2007 (1)

[3] Huang Ningyi, Wu fold.From the perspective of cognitive linguistics and teaching complement [J]. Journal of Hunan University of Science and Technology, 2010 (8)

[4] He Xiaotao. ESP teaching based on independent college college English teaching reform [J]. Journal of Minxi Vocational and Technical College, 2014 (16)

[5] Misunderstanding and prejudice: the key to the development of ESP teaching in our university

[J]. Foreign Language Teaching, 2013 (34)

[6] Strevens, P. “ESP after Twenty Years: A Re-appraisal”. In M. Tickoo (ed.) ESP: State of the Art [C]. Singapore: SEAMEO Regional Language Center, 1988.

[7] Dudley-Evans, T. Developments in English for Specific Purposes: A Multi-disciplinary approach[M]. Cambridge: Cambridge University Press, 1988.

[8] Lewis, M.\& J.Hill. Source Book for Teaching English as a Foreign Language[M].Hong Kong: Macmillan Publishers Limited, 2003. 